in training colleges. During the year, eighteen one-day study conferences, attended by some 2,690 students, were heId in these colleges, and in addition 60 conferences on similar lines were held for students at technical colleges and the sixth forms of grammar schools all over Britain. Two types of special courses are now offered to training college students, one academic and the other professional. The academic courses consist of a series of 'sample studies', and the short professional courses are designed to show students the services that the Institute can give, and also provide them with practical experience.

\section{The City Museum, Sheffield}

WIтн no changes in the membership of the staff, the annual report of the City Museum, Sheffield, for the year ended March 31, 1963, records a period of stability and forward planning (Pp. $18+4$ plates. Sheffield: City Museum, 1964). This was especially evident in the formulation of a definite archæological policy incorporating specific recommendations regarding records, research, collecting, excavation and publication. The Schools Service is rapidly expanding its activities, the most popular subjects being history, including the development of Sheffield's industries, ancient history and natural history. The Museum's meteorological station was also a frequent choice for talks and demonstrations. The compilative note on the glass industry of South Yorkshire deserves more permanent publication in the journal of a local society as it will be lost in such an ephemeral place as an annual report. An impressive series of exhibitions were staged during the year. The list of events arranged for the Sheffield Museum Society showed imagination and a determined effort to attract members of varying interests.

\section{The Museum of History and Technology, Smithsonian Institution}

A RECENTLY published booklet presents in a permanent form the speeches made at the dedication of the Museum of History and Technology of the Smithsonian Institution on January 22 (Dedication of the Museum of History and Technology of the Smithsonian Institution. Pp. 26. Smithsonian Publication No. 4531. Washington, D.C.: Smithsonian Institution, 1964). The retiring secretary of the Institution, Dr. Leonard Carmichael, who presided, expressed gratitude to all concerned in the building, while the chancellor, Mr. Earl Warren, outlined the history of the Smithsonian. Senator Clinton P. Anderson emphasized the historically significant role that the Congress of the United States has played in the development of the Smithsonian. The President of the United States dedicated the building and said that "the more we understand the meaning of the past, the more we appreciate the winning of the future".

Dr. Leonard Carmichael has been succeeded by Dr. S. Dillon Ripley II as secretary of the Institution (Nature, 201,243 ; 1964).

\section{The $\mathrm{C}^{0}$ Resonance}

THe recent discovery of the $\Omega$ - particle has given considerable support to the ideas of unitary symmetry. According to this theory, which is an extension to the concept of isotopic spin, elementary particles fall into sets of $1,8,10,27 \ldots$ members, each with the same spin and parity, and with roughly equal and related masses. The $\Omega^{-}$completed a set of ten particles of spin $3 / 2$ and positive parity. The $\mathrm{C}^{0}$ resonance recently announced at CERN (Physics Letters, 9, 207; 1963) could be the first of a new set of spin 1 and positive parity. though it is possible that the $B$ resonance, already observed, has these same quantum numbers. In this case, these could both be members of the same octet, as they have roughly equal masses. The resonance was discovered in an investigation of the annihilation of antiprotons on protons, and decays into a $K$ meson and two $\pi$ mesons with a lifetime of $10^{-20}$ sec, so that it is only seen as an enhancement of the $K \pi \pi$ distribution at the energy of the resonance, $1.23 \mathrm{GeV} / \mathrm{c}^{2}$. The spin and parity have only been provisionally estimated, and the isotopic spin not determined at all; it may be $\frac{1}{2}$ or $3 / 2$. If the latter is the value, the $\mathrm{C}^{0}$ would have to belong to a set of at least 10 members.

\section{Mineragraphic Investigations in Australia}

MineRAGRAPHY, a rather unusual term defined as one that is ". . . particularly associated with the study of ore minerals by reflected light microscopy using polished sections ....", according to the Commonwealth Scientific and Industrial Research Organization in its annual report for 1962-63 (Pp. 11. Melbourne: Commonwealth Scientific and Industrial Research Organization, 1963). The C.S.I.R.O. Mineragraphic Investigations Group was originally established to provide this technique as a service for Australian mining companies, but it has so far extended its facilities to cover the examination of minerals and rocks of all kinds that ". . . it has become a general reference point in the organization for most problems concerned with the nature, origin and utilization of such materials". Although the investigation of metallic ores still forms the most important section of the Group's work, the range of projects undertaken has been facilitated by the installation of additional equipment, notably for microscopy, cartography, photography and X-ray diffraction studies - the last-mentioned was made possible by contributions from certain mining companies through the good offices of the Australasian Institute of Mining and Metallurgy. As the report briefly shows, the investigations undertaken are varied and include: examination of heavy mineral sands; oil exploration samples; brown coal and associate materials; tin ores; gold; copper; pogmatite mineralogy; bauxite, laterite, magnesite and gypsum deposits; sand drift at Portland, Victoria: a contribution to the U.N. Conference on "The Application of Science and Technology to Less Developed Areas", held at Geneva. It is noted that: "The work at Portland has been the major Australian application of heavy mineral marker techniques to the investigation of coastal sand movements and the potential effect of these on siltation of harbours". Similar projects of the same type are in hand, concerned with foreshore reclamation, also the search for suitable harbour sites along the Wostern Australian coastline.

\section{The Registrar General's Quarterly Return}

Tre Registrar General's Quarterly Return for the fourth quarter of 1963 which has recently been published enables a provisional assessment to be made of the vital statistics for that year (Quarterly Return for England and WalesBirths, Deaths and Marriages; Infectious Diseases ; Weather ; Population Estimates, Quarter ended 31st December, 1963. Pp. 28. No. 460, 4th Quarter, 1963. London: H.M.S.O., 1964. 2s. 6d. net). Live births at 856,000 were higher than in any year since 1947 , when the number was 881,000 . Deaths at 572,000 were also higher, but the natural increase of 284,000 compares with an average of 230,000 during the years 1957-61. The infant mortality continues to drop and, for the year as a whole, was the lowest on record at 20.9 per thousand live births, and 0.9 points lower than in the previous year. The resumption in its fall is particularly gratifying in view of its relative stickiness during the past four years. The seasonally adjusted figures for live births show a welcome check during the fourth quarter of 1963 , but it is too early yet to say whether the check is moro than temporary. Latest projections published in the return estimate an increase in the population of England and Wales of 17.7 million during the next forty years; the decennial estimated rates of increase for the next four decades being $7 \cdot 8,7 \cdot 3,8 \cdot 5$ and $9 \cdot 5$ per cent, respectively. 